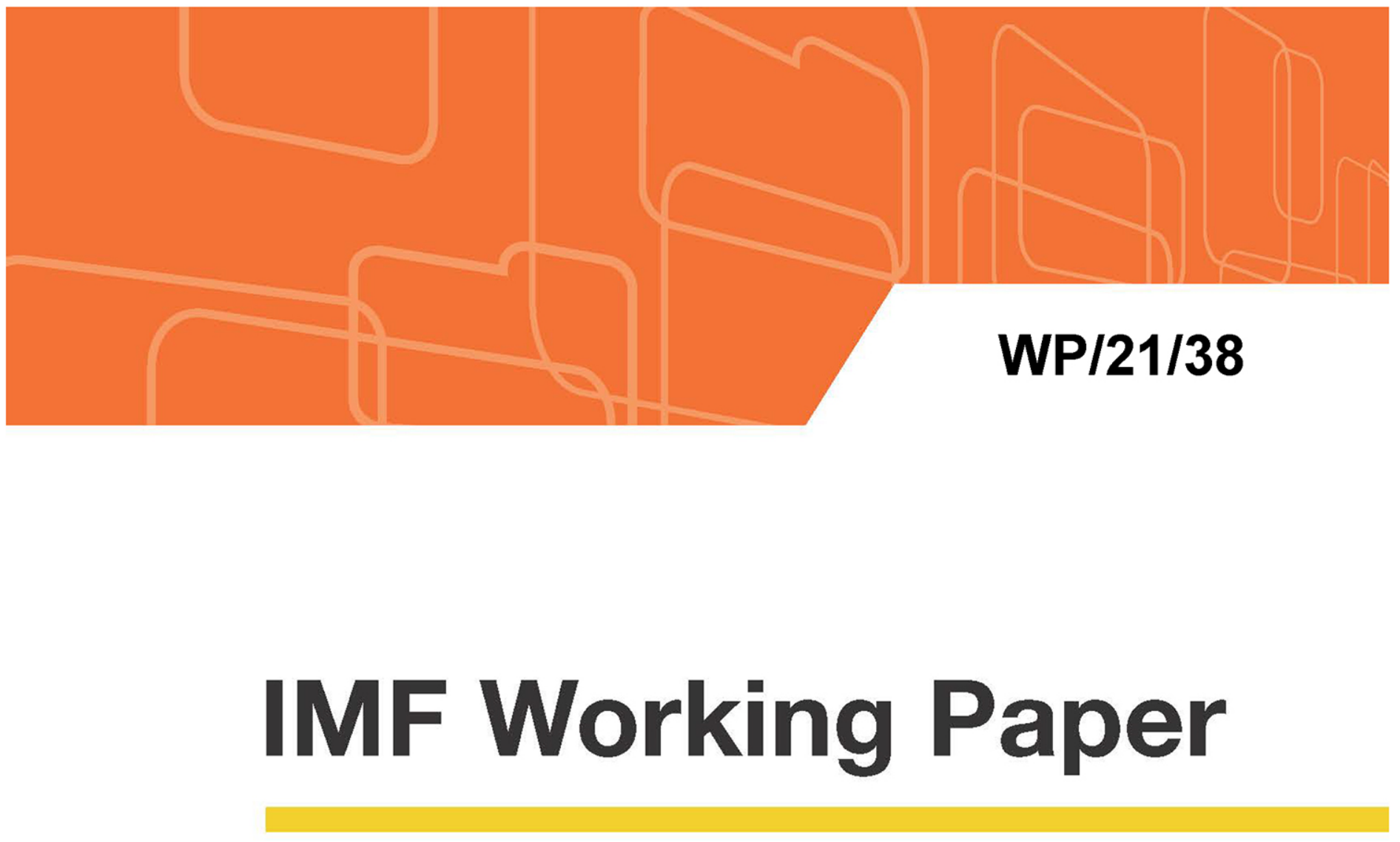

\title{
Regional Disparities, Growth, and Inclusiveness
}

by Holger Floerkemeier, Nikola Spatafora, and Anthony Venables

IMF Working Papers describe research in progress by the author(s) and are published to elicit comments and to encourage debate. The views expressed in IMF Working Papers are those of the author(s) and do not necessarily represent the views of the IMF, its Executive Board, or IMF management. 


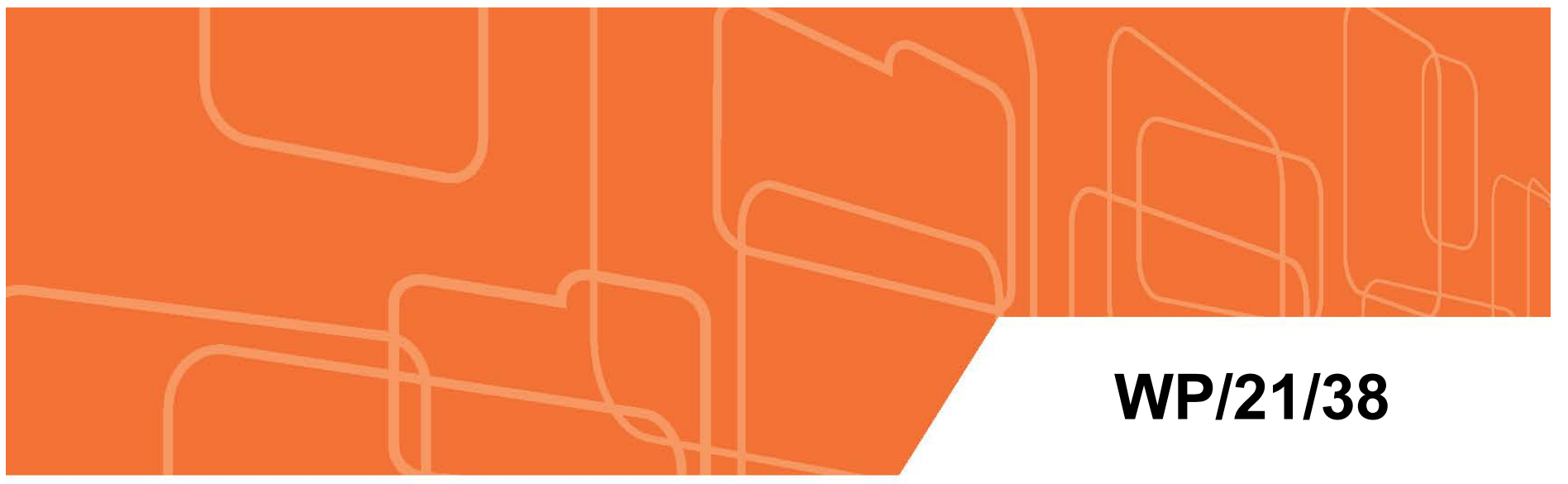

\section{IMF Working Paper}

Regional Disparities, Growth, and Inclusiveness

by Holger Floerkemeier, Nikola Spatafora, and Anthony Venables

IMF Working Papers describe research in progress by the author(s) and are published to elicit comments and to encourage debate. The views expressed in IMF Working Papers are those of the author(s) and do not necessarily represent the views of the IMF, its Executive Board, or IMF management.

$$
\text { I N T E R N A T I O N A L M O N E T A R Y F U N D }
$$




\title{
IMF Working Paper
}

Institute for Capacity and Development

\section{Regional Disparities, Growth, and Inclusiveness}

\section{Prepared by Holger Floerkemeier, Nikola Spatafora, and Anthony Venables ${ }^{1}$}

Authorized for distribution by Paul Cashin and Valerie Cerra

February 2021

\section{IMF Working Papers describe research in progress by the author(s) and are published to elicit} comments and to encourage debate. The views expressed in IMF Working Papers are those of the author(s) and do not necessarily represent the views of the IMF, its Executive Board, or IMF management.

\begin{abstract}
We discuss regional disparities in economic performance and living standards. We first set out some key facts, and provide a conceptual framework to help analyze whether such disparities are efficient, or instead reflect market and/or policy failures. We examine whether policy attempts to reduce regional disparities necessarily involve a trade-off between equity and efficiency. We then investigate whether policymakers should focus on boosting the economic performance of lagging regions - or, conversely, accept the presence of regional disparities, and instead assist households in lagging regions through transfer payments, investments in education, health, and other basic services, and by facilitating out-migration.

JEL Classification Numbers: R11, R12, R58.

Keywords: Regional Disparities, Place-Based Policies, Inclusive Growth.

Authors’ E-Mail Addresses: hfloerkemeier@jvi.org, nspatafora@,imf.org, tony.venables@economics.ox.ac.uk

\footnotetext{
${ }^{1}$ We are grateful for comments provided by Andy Berg, Carlos Caceres, Valerie Cerra, Gilles Duranton, Barry Eichengreen, John Spray, Zhongxia Zhang, and participants in the Inclusive Growth book seminar series organized by the IMF Institute for Capacity Development. This is a draft of a chapter that has been accepted for publication by Oxford University Press in the forthcoming book "How to Achieve Inclusive Growth", edited by V. Cerra, B. Eichengreen, A. El-Ganainy, and M. Schindler.
} 


\section{Contents}

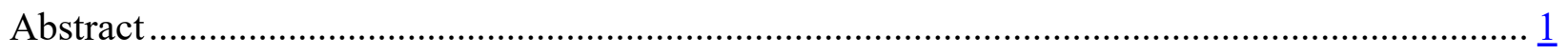

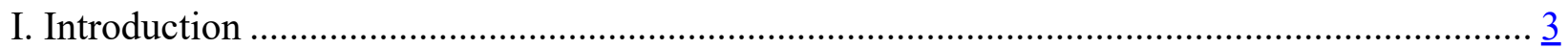

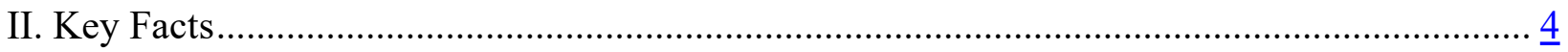

III. Drivers of Regional Disparities: Conceptual Framework..................................................... 11

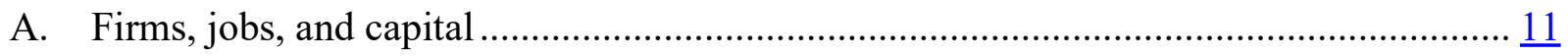

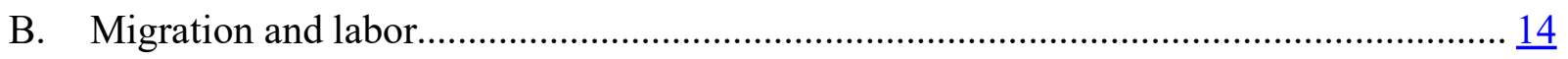

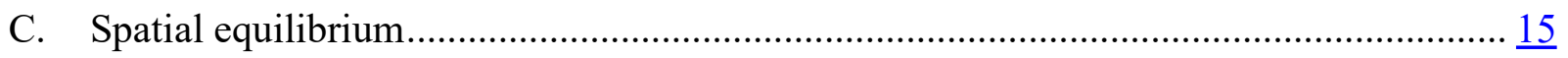

D. Growth and regional disparities in developing countries ............................................. 15



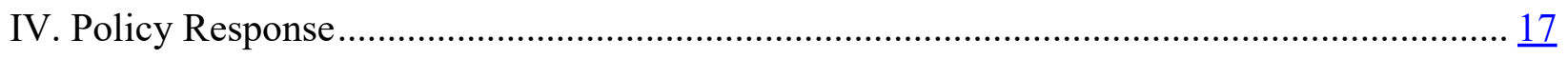

A. Spatially blind, spatially connective, and spatially targeted policies................................ 17

B. Firms, jobs, and capital ...................................................................................... 19

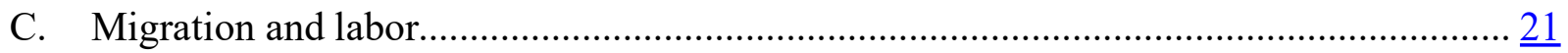

D. Choice of measures and implementation considerations ................................................. 22

E. Case studies: German reunification, and the Italian Mezzogiorno ……………………... $\underline{24}$

German reunification .......................................................................................... 24

The Italian Mezzogiorno ………………………………............................................ 25

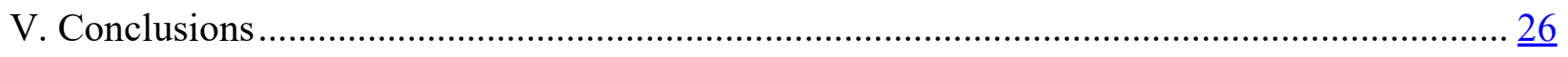

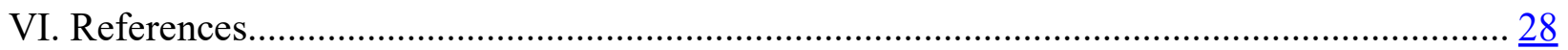




\section{INTRODUCTION}

Many countries are characterized by significant regional disparities in economic performance and living standards, as reflected in income, education, or health outcomes. These regional disparities raise equity concerns: they contribute to overall within-country inequality, and they are linked to inequality of opportunity, as measured by, say, intergenerational mobility. ${ }^{2}$ Regional disparities may also have harmful implications for economic efficiency, as limited opportunities for those stuck in the wrong place lead to the underutilization of potential and constrain overall growth. ${ }^{3}$ More broadly, regional disparities, including urban-rural differences, can fuel social tensions and pathologies (Case and Deaton 2020), promote political polarization (Wilkinson 2019), increase populism and resentment towards urban elites (RodríguezPose 2018, Kessler 2018, Muro and Liu 2016, Shearer 2016), threaten countries' social fabric and national cohesion, and in extreme cases lead to conflict, particularly where the disparities reinforce existing ethnic, racial, linguistic, or religious divisions.

Large and/or rising regional disparities may arise in different contexts. In some cases they may be a normal feature of growth. The concentration and specialization of production can boost overall economic productivity, but will do so unevenly across regions: "development does not bring economic prosperity everywhere at once; markets favor some places over others" (World Bank 2009). Favored areas will then pull away from other regions, which may experience economic decline in relative and possibly absolute terms; but dispersing production more broadly across regions could lower aggregate productivity and reduce economic growth. In other cases, regional disparities may be a consequence of adverse economic shocks that have impacted particular regions. Adjustment to these shocks can be very slow, giving rise to persistent disparities.

All this raises three broad sets of questions. First, what economic forces will dampen, or conversely amplify, regional disparities? Second, if market forces alone do not bring about convergence across regions, are the resulting regional disparities in fact efficient, or do they instead reflect market and/or policy failures? As a corollary, will policy attempts to reduce regional disparities necessarily involve a trade-off between spatial equality and growth, between equity and efficiency? Finally, should there be a policy response, and if so what form should it take? Is geographically "balanced growth" a precondition for inclusiveness, and should policy focus on boosting the economic performance of lagging regions? Or should policymakers accept the presence of regional disparities in productivity, and instead assist households in lagging regions

\footnotetext{
${ }^{2}$ A child born in San Francisco in the bottom 20 percent of the national income distribution has twice as much chance of ending up in the top 20 percent as an adult than a similar child born in Detroit (Equality of Opportunity project).

${ }^{3}$ Countries with larger regional disparities experience lower long-term growth (Che and Spilimbergo 2012).
} 
through transfer payments, investments in education, health, and other basic services, and by facilitating out-migration?

This chapter first presents some key stylized facts regarding regional disparities. It then sets out a conceptual framework to interpret these facts and analyze the drivers of disparities, and concludes with a discussion of potential policy responses.

\section{KEY FACTS}

Levels of economic activity and welfare differ sharply across sub-national regions, in both advanced and developing economies. This inequality is evident when looking at output or income. In advanced economies, real GDP per capita in leading regions is now on average 70 percent higher than in lagging regions (Figure 1, top panel). ${ }^{4}$ In developing economies, regional disparities are even larger, about twice the size of those in advanced economies (Figure 1, bottom panel). Such regional disparities are also reflected in labor-market performance (for instance, labor productivity, employment, and wages) and indicators of human development (for instance, education and health outcomes) (Figure 2; see also Avitabile et al. 2020).

In advanced economies, regional disparities have broadly increased since the late 1980s, as affluent places, in particular large, well-connected cities, pulled away from poorer ones. This represents a marked contrast to the steady decrease in disparities between the end of World War II and the 1980s (Figure 1, top panel). In the OECD, the average labor productivity gap between the most productive 10 percent of regions and the bottom 75 percent widened by nearly 60 percent over the past 20 years. ${ }^{5}$ In the United States, inter-regional income inequality is at its highest point in a century (Kemeny and Storper 2020). The share of output generated by the top four metropolitan areas has risen across a wide range of industries, ${ }^{6}$ the gap in employment rates between leading and lagging regions has steadily widened (Austin et al. 2018), and innovative sectors have grown fastest in those areas where they were relatively large to begin with (Atkinson et al. 2019). Relatedly, the average pace of convergence between leading and lagging regions has decreased markedly over the past five decades, and is now close to zero (Figure 3, top panel). Again, this contrasts markedly with the remarkably broad and uniform spatial convergence previously observed within the United States (Barro et al. 1991, Barro and Sala-i-Martin 1992),

\footnotetext{
4 "Leading" and "lagging" regions are defined here as those at, respectively, the $90^{\text {th }}$ percentile and the $10^{\text {th }}$ percentile of the within-country distribution. Subnational regions are the TL2 regions as defined in OECD (2018); these are typically the first-level administrative units within a country, corresponding roughly to U.S. states or German Länder.

${ }^{5}$ From US\$15,200 to US\$24,000 (OECD 2016).

${ }^{6}$ Between 2002 and 2014, it rose from 18 percent to 29 percent for financial services, and from 15 percent to 21 percent for trade and logistics.
} 
Canada (Coulombe and Lee 1995), the European Union (both as a whole and within individual countries; Neven and Gouymte 1995, Persson 1997, De La Fuente 2002), and Japan (Sala-i-Martin 1996). The rate of economic convergence across U.S. states during 1990-2010 was less than half that observed during 1880-1980, and it has since fallen close to zero; likewise, convergence across EU regions largely stopped after the mid-1980s (Martin 2001). However, while the wage premium associated with working in large cities has increased sharply for skilled workers, it has mostly disappeared for the less skilled (Gaubert et al. 2021b, Autor 2019, Abel and Deitz 2019, Giannone 2019, Vanheuvelen and Copas 2019, De La Roca and Puga 2017). Relatedly, cities with more vibrant labor markets have a lower share of less skilled, low-wage workers (Ross and Bateman 2019); and, at least in the United States, while college-educated workers have been steadily moving into affluent cities, non-college workers have been moving out (Ganong and Shoag 2017). That said, the trends in regional disparities vary sharply across countries; and regional disparities account for a much larger share of overall inequality in some countries than in others. $^{7}$

Further, in advanced economies, the rise in regional disparities appears to be associated with negative economic shocks and de-industrialization since the 1980s. Lagging regions are typically more concentrated in slow-growing manufacturing and agriculture, and less concentrated in the faster-growing service sectors, than leading regions. Much research highlights the impact of trade shocks. For instance, China's rapid export growth had a particularly adverse impact on those advanced-economy regions initially specialized in the manufacturing industries that became subject to increased import competition (Autor et al. 2013, 2013b). Other research suggests a large impact from automation, particularly on smaller, more rural regions (Muro et al. 2019). Under either interpretation, some regions fell behind because of their failure to adjust to adverse shocks; for instance, advanced-economy regions that experienced closures of automotive manufacturing plants after 2000 saw their unemployment rate rise relative to other regions within the same countries (IMF 2019). And the impact of shocks proved larger where adjustment was hampered by less open and flexible labor and product markets.

\footnotetext{
${ }^{7}$ The regional component of household disposable income inequality is less than 1 percent in Austria, but more than 10 percent in Italy (IMF 2019). Again, subnational regions here are typically the first-level administrative units within a country, corresponding roughly to U.S. states or German Länder.
} 
Figure 1. $90^{\text {th }}$ percentile $/ 10^{\text {th }}$ percentile of regional real GDP per capita, average across advanced economies, 1950-2016 (top panel), and emerging markets, 1980-2016 (bottom panel).
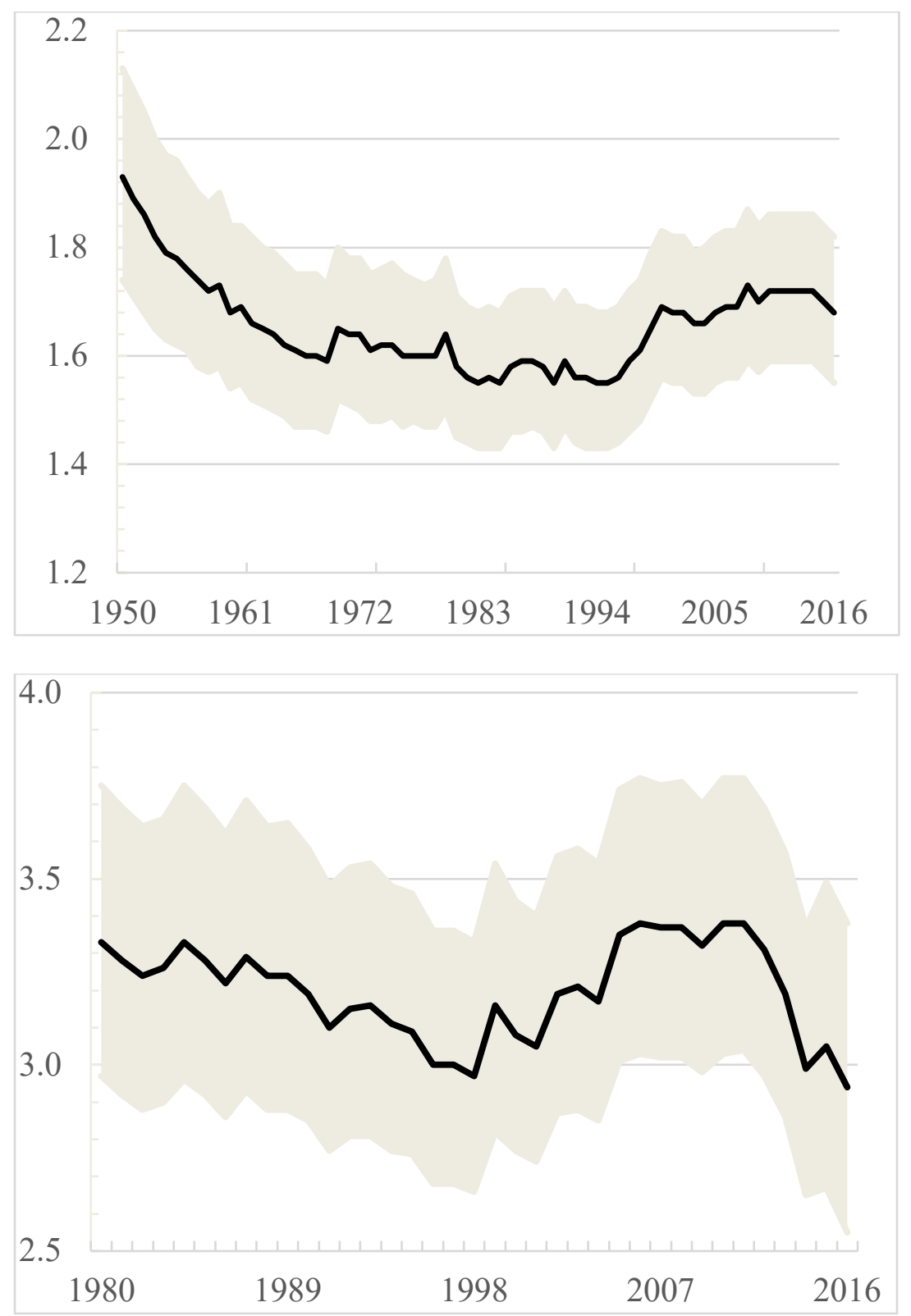

Source: IMF (2019), figure 2.1. License: CC BY 3.0 IGO.

Note: The 90/10 ratio for a country is defined as real GDP per capita in the region at the $90^{\text {th }}$ percentile of the country's regional real GDP per capita distribution relative to that in the region at the $10^{\text {th }}$ percentile. The solid line shows the year fixed effects from a regression of country-specific 90/10 ratios on year fixed effects and country fixed effects; this procedure accounts for entry and exit during the period and level differences in the 90/10 ratios. The shaded areas indicate the associated 90 percent confidence interval. 
Figure 2. Human capital and labor market outcomes, lagging regions versus other regions, average across advanced economies, latest available year (percentage point difference, unless otherwise noted).

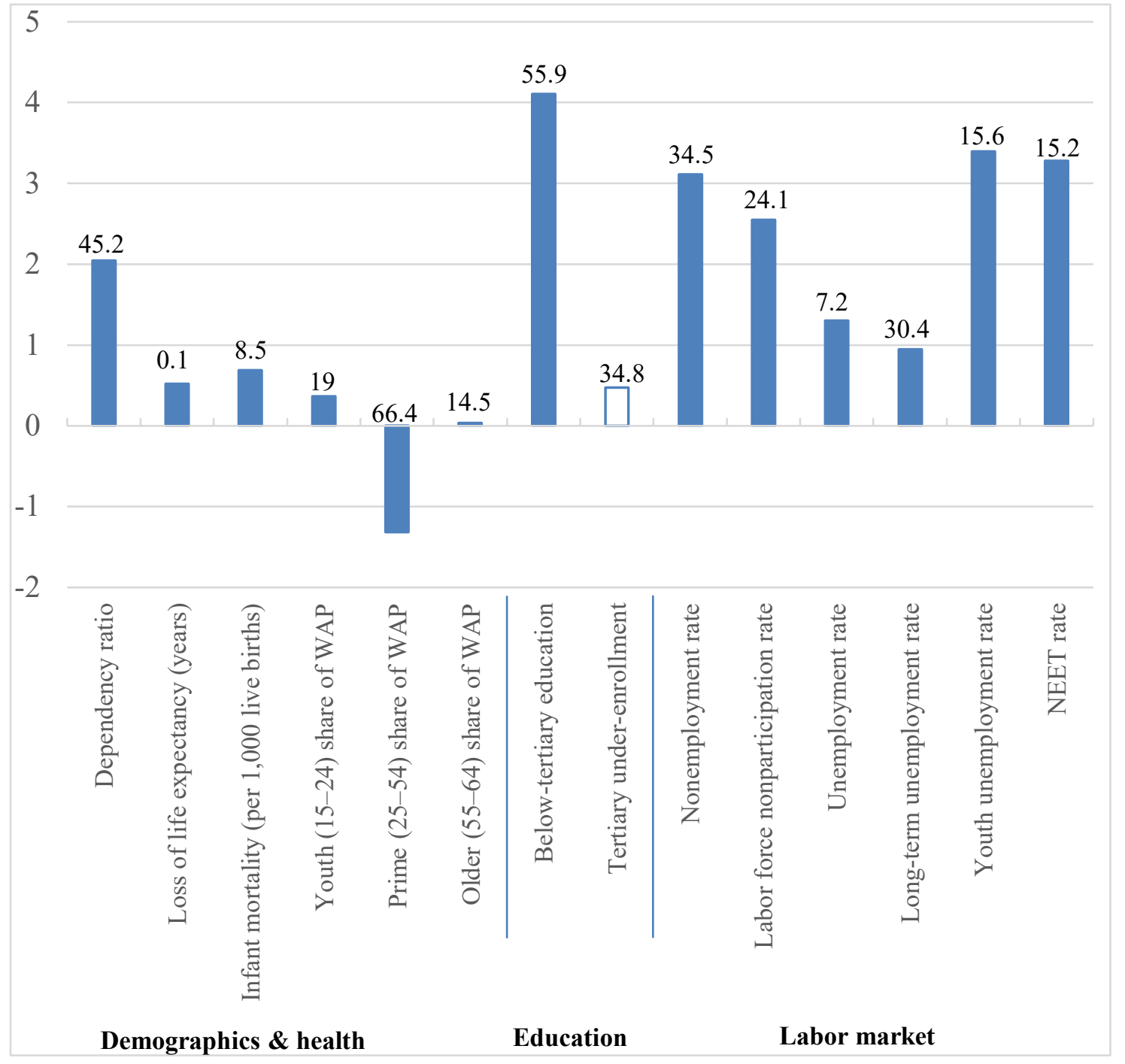

Source: IMF (2019), figure 2.4. License: CC BY 3.0 IGO.

Note: For each variable, bars show difference between lagging regions and other regions; numbers above bars show sample average of variable. Lagging regions defined as those with real GDP per capita below their country median in 2000 and with average growth below country's average over 2000-16. Results based on regressions of each variable on an indicator for whether region is lagging, controlling for countryyear fixed effects, with standard errors clustered at country-year level. Solid bars indicate estimated coefficient on lagging indicator is statistically significant at $10 \%$ level. Positive estimated coefficients indicate worse performance by lagging regions. Tertiary under-enrollment $=$ difference in percent of population enrolled in tertiary education in other regions versus lagging regions. Nonemployment rate $=$ 100 - employment rate. Labor force nonparticipation rate $=100$ - labor-force participation rate of workingage (15-64) population. Unemployment rate = share of working-age labor force that is unemployed. Longterm unemployment rate $=$ share of working-age labor force unemployed for one year or more. Youth unemployment rate $=$ share of youth (15-24) labor force that is unemployed. NEET rate = percent of youth population that is not in education, employment, or training. WAP = working-age population. 
Figure 3. Speed of regional convergence (percent), average across advanced economies, 19702016 (top panel), and emerging markets, 2000-2016 (bottom panel).
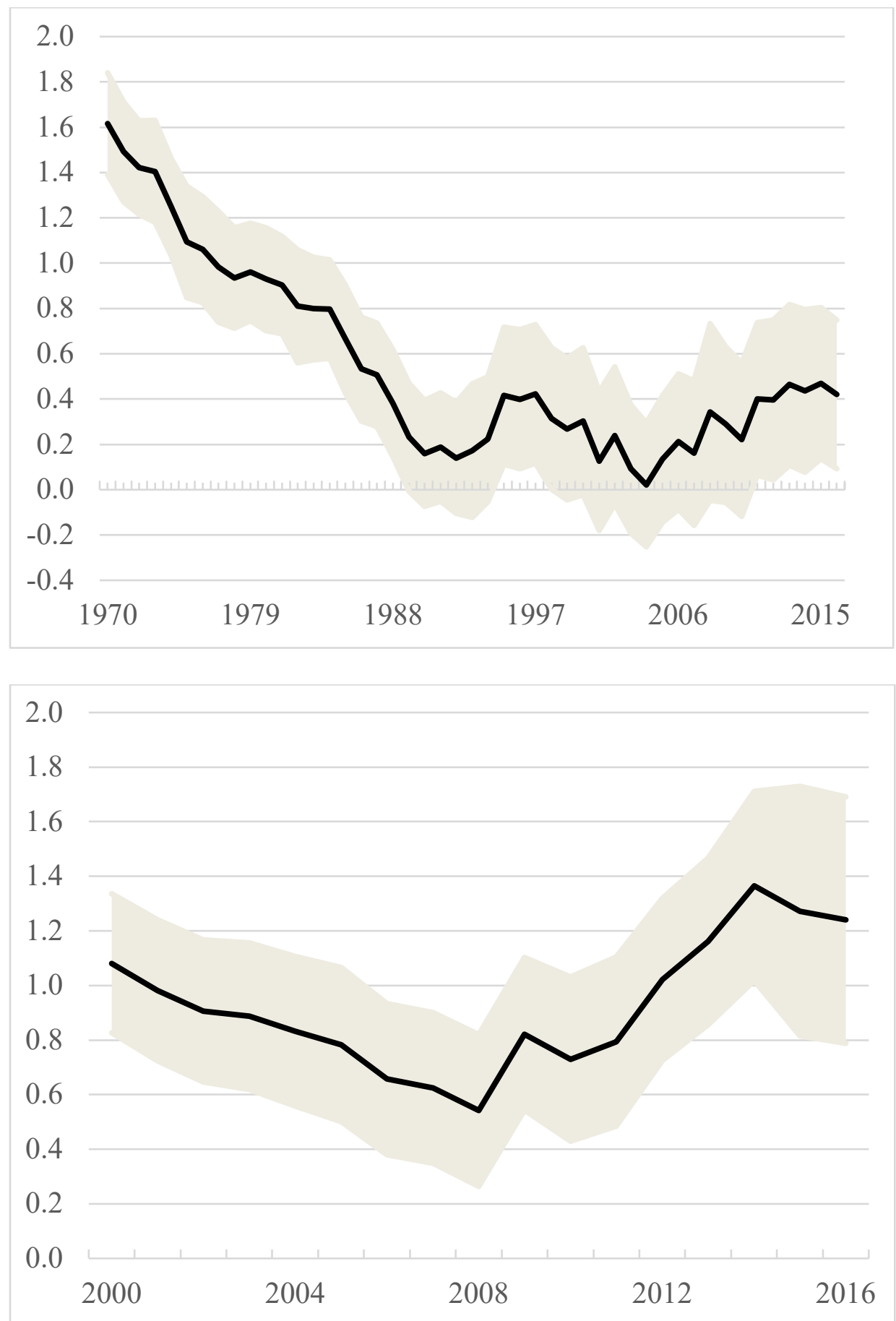

Source: IMF (2019), figure 2.1. License: CC BY 3.0 IGO.

Note: The figure depicts the coefficient on initial regional log real GDP per capita from a cross-sectional regression of average regional real purchasing power parity GDP per capita growth on initial regional log real GDP per capita, estimated over 20-year rolling window. The regression includes country fixed effects, so it indicates average within-country regional convergence. The coefficient is expressed in annualized terms, indicating the average annual speed of convergence. 
Figure 4. As economies develop, GDP concentrates in cities and leading regions.

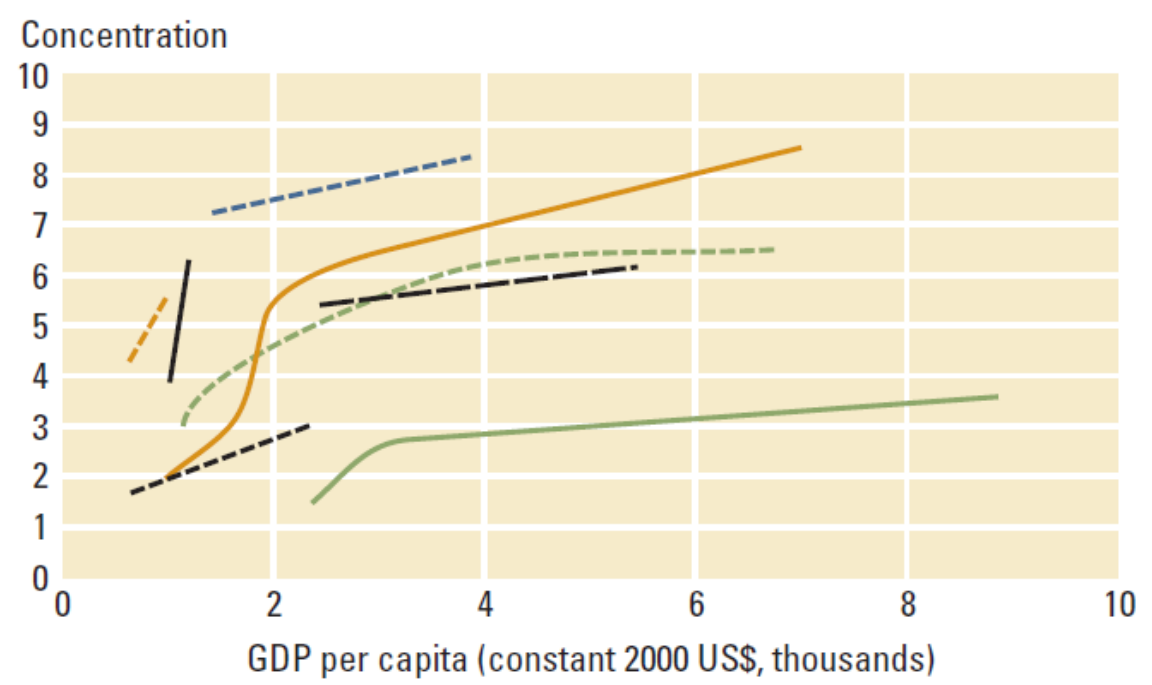

\begin{tabular}{|ll|}
\hline ---- Indonesia, 1989-2005 & ---- Spain, 1850-1960 \\
--- Thailand, 1975-2004 & --- Brazil, 1960-2004 \\
- France, 1801-1963 & Netherlands, 1850-1960 \\
\hline Philippines, 1980-2005 & - Chile, 1976-2004
\end{tabular}

Source: World Bank (2009), figure 2.2. License: CC BY 3.0 IGO.

Note: The concentration measure is defined as follows. First, an area's hypothetical share of national GDP is estimated under the assumption that national GDP exhibits a uniform spatial distribution. Second, the area with the highest actual share of national GDP is identified. Third, the actual GDP share of this leading area is divided by its hypothetical (uniformly spatially distributed) share to yield a measure of spatial concentration. For example, if the leading area has an actual share of 10 percent and a hypothetical share of 2 percent, then the concentration measure equals 5. See World Bank (2009) for details.

In developing economies, as discussed, regional disparities in GDP per capita are even larger. Further, such differences in economic activity translate even more directly into differences in living standards. ${ }^{8}$ However, the limited data available do not point to broad-based increases in disparities (Figure 1, bottom panel), and on average suggest continued convergence between leading and lagging regions (Figure 3, bottom panel), over the past two decades. Similar conclusions emerge when analyzing disparities within individual large emerging markets such as Brazil and India (Nagaraj et al. 2000).

Importantly, in developing economies, economic takeoffs are often associated with the emergence of regional disparities. That is, regional disparities here may be symptomatic of positive rather than negative shocks. Economic development, in its early stages, leads to the rapid

\footnotetext{
${ }^{8}$ In developing countries, real household consumption levels are approximately 75 percent higher in leading regions than in lagging regions. For advanced economies, the corresponding consumption gap is less than 25 percent (World Bank 2009).
} 
concentration of economic activity in locations close to markets. Such favored locations include cities, often capitals and primary cities in particular, and leading regions (Figure 4), for instance areas near large cities, as well as coastal areas that are more open to international trade. As Thailand industrialized, activity rapidly concentrated in the Bangkok metropolitan area; in Brazil, concentration in the Sao Paulo metropolitan area also rose. These leading regions diversify out of agriculture and into higher-productivity manufacturing, with significant changes in both sectoral employment mixes and sectoral productivity.

As economic development proceeds, regional disparities in living standards between leading and lagging regions at first widen, but then typically stabilize and eventually decline (World Bank 2009). Regional differences in wages, income, and access to public services typically prove long-lived. However, over time, prosperity tends to spill over to other areas that are, or are made, well connected to the leading regions. The divergence and re-convergence are likely to occur faster in more dynamic areas and countries. This is an important mechanism behind the Kuznets curve - the hypothesis that as an economy develops, market forces first increase and then decrease economic inequality, including across regions. This pattern was evident in today's advanced economies as they industrialized. In the United Kingdom, regional disparities (as measured by the coefficient of variation of GDP per capita) increased by almost 40 percent between 1871 and 1911, before stabilizing and then slowly converging until the late 1970s (Crafts 2005). In the United States, disparities in GDP per capita across states increased between 1840 and 1880, but then slowly began to narrow. In France, the dispersion of wages across départements increased between 1855 and 1900, when convergence set in. In Canada, the dispersion of gross value added per capita between provinces increased between 1890 and 1930, but then started falling. And a similar pattern can be seen in today's developing economies. For instance, regional inequality widened sharply in the fast-growing East Asian economies between the early 1990s and the late 2000s (Kanbur et al. 2014). China experienced the most dramatic increase in regional disparities, with output per capita in the coastal regions rising to more than twice the level in the inland regions. More recently, these regional disparities in living standards have started to stabilize. In India, coastal states have also fared better than inland states over the past two decades. And, across Eastern Europe, regional disparities widened sharply after the beginning of transition. That said, in these fast-growing economies, all subnational areas generally experienced gains in wages and income, even though leading regions benefited the most. And in relatively closed, slower-growing economies, such as Brazil and Colombia, regional disparities have decreased over time, even where population continued to concentrate.

Are current trends intensifying economic concentration, and both amplifying regional disparities and making them more persistent? Rising spatial concentration and typically rising regional disparities characterized today's developed economies when they industrialized; for instance, Korea after 1970. But globalization and technological progress, including improved transportation and communications infrastructure, may be increasing the market potential of leading versus lagging regions over time. To make sense of such issues, we now develop a conceptual framework. 


\section{DRIVERS OF REgIONAL DiSPARITIES: CONCEPTUAL FRAMEWORK}

Spatial unevenness in economic activity is startling, with 55 percent of the world population concentrated in 1 percent of the world land area. This is partly natural, driven by soil fertility, rainfall, natural resources, and trade possibilities. And it is partly driven by the costs and benefits of clustering people and activity together, and the tension between forces for dispersion versus clustering of economic activity. The dispersion forces arise, in the broadest terms, from diminishing returns: if putting more activity in a particular place runs into diminishing returns, then activity will spread out. The clustering forces are driven by increasing returns: these mean that the more activity there is in a place, the higher the value of moving there.

Spatial unevenness is a particular concern when it reflects disparities in the distribution of not just economic activity, but also income per capita and well-being. Such disparities are widespread and quite persistent. Standard economic models suggest that, within a country or region where labor and firms are mobile, there should be little spatial variation in the real income of people with similar attributes. Two mechanisms would ensure this. First, jobs would move to lower-wage regions - or, in a growing economy, new job creation will be slanted towards such regions. Second, people would move to higher-wage regions. Why do these mechanisms not work, or at least only work slowly? We discuss first the movement of jobs, and then that of workers and households.

\section{A. Firms, jobs, and capital}

Firms' location decisions are shaped by multiple forces. In many sectors proximity to customers is all-important, as goods or services do not travel well or have to be supplied face-toface. Other sectors, such as natural-resource intensive sectors, locate close to raw materials. In sectors not dominated by these forces, location decisions depend on factors including wages, productivity, the supply of suitably skilled labor, and ease of access to customers and to suppliers of intermediate goods and services.

These factors have a spatial dimension, particularly as firms derive advantages from proximity to other firms and to households- "agglomeration economies". Agglomeration effects reflect the economies of scale that arise between firms, and also between firms, households, and workers (Duranton and Puga 2004, 2020; Puga 2010; Rosenthal and Strange 2004). Some of these benefits arise simply from cost saving. If your customers and suppliers are close by, they can be reached at low cost; just-in-time operation requires both frequent and reliable deliveries, easier to secure if suppliers are nearby. Other benefits arise as there are often knowledge spillovers 
between firms. ${ }^{9}$ These effects are manifest particularly in the tendency of firms in R\&D-intensive sectors to cluster together.

Agglomeration benefits also arise because of scale and specialization. Larger and denser markets allow for scale, scope, and specialization. Specialist suppliers and workers represent a good example. The larger the market, the more likely that a firm or worker will find it worthwhile to specialize and hone skills in producing a particular good or service. This specialization creates high productivity. And, while customers pay for the product, they are likely to also receive some net benefit, over and above what they pay. This creates a positive feedback. Customers will be attracted to a place with multiple suppliers, thereby growing the size of the market, and making it attractive for further and more specialized suppliers to set up operations. This is the classic process of growing a 'business ecosystem' and of cluster formation. ${ }^{10}$

The agglomeration process operates at several different levels. In the supply of intermediate goods between firms, it is the basis of the 'linkages' discussed in an old development economics literature, and in the 'new economic geography' research (Fujita et al. 1999). Between firms and final consumers, it is the basis of Krugman's 'core-periphery' model (Krugman 1991). And in the labor market, it takes the form of thick market effects that allow for better matching of firms to workers. In some contexts these agglomeration economies are based on overall economic activity in an area - the size and diversity of the labor force, and the level of demand for goods and services. In others they involve sector-specific knowledge spillovers, specialist labor skills, and demand and supply linkages in related sectors. The strength of different effects varies widely across sectors.

Agglomeration implies spatial differences in productivity. There is significant research on the extent to which firm productivity varies with access to economic size. Economic size typically refers to an area such as a city or travel-to-work area, and is measured in different ways, such as urban population, or more sophisticated measures of market access or the 'effective density' of a city or region. A consensus view is that, after controlling for variation in labor-force characteristics (skills, age, and in some cases occupation), the elasticity of productivity with respect to economic size is around 3-6 percent in advanced economies (Combes and Gobillon 2015, Rosenthal and Strange 2004). This means that each doubling of economic size raises productivity by around 5 percent, so that a city of 5 million has productivity 20-30 percent higher than one of 200,000, numbers that align well with casual observation of London or New York as compared to smaller towns and cities. Of course, these are average numbers, and the productivity advantage of urban areas will show up in different degrees in different sectors, and affecting different types of labor.

\footnotetext{
9 'The mysteries of the trade become no mysteries; but are as it were, in the air'-Marshall (1920), writing about the $19^{\text {th }}$ century Sheffield metals cluster.

${ }^{10}$ Technically, these are positive pecuniary externalities between firms, not internalized by market decisiontaking.
} 
For example, in advanced countries regional disparities in the wages of skilled labor have increased much more in recent years than has been the case for unskilled labor.

Agglomeration effects are possibly much larger in developing countries. There, weaknesses and wide variation in the provision of physical infrastructure (such as transportation, communications, and power), in education, and in provision of public services, significantly reduce the attractiveness of lagging places for investment unless offset by correspondingly large wage differentials (World Bank 2009). Estimates based on variations in productivity across urban areas in developing countries suggest an elasticity of productivity with respect to city size of around 8 percent, twice that in developed economies (Chauvin et al. 2017, Glaeser and Xiong 2017). Regional productivity and earnings differentials are amplified further by the presence of informal sectors and traditional agricultural activities, whose productivity may be four or five times lower than that of modern sector urban activities (Gollin et al. 2014).

Agglomeration economies imply that regional disparities may prove persistent. There is a 'first-mover' or coordination problem: no firm wants to leave an existing cluster and forego the associated productivity benefits. Coordinated movement by many firms might be collectively profitable, but the market mechanism cannot achieve this. This is because, while each firm creates benefits for other firms, these do not enter its decision taking. It follows that even large wage differences between regions may be insufficient to induce firms to locate in a lagging region, rather than in an established center. A further implication is that there are threshold effects and 'tipping points'. Policy changes below some threshold may be wholly ineffective, while a 'big-push' of policy across a range of actions may stand a greater chance of success (Murphy and Shleifer 1989).

Agglomeration effects also imply that transport and infrastructure improvements, and 'connectivity' more broadly, have ambiguous effects-but at some point are likely to reduce disparities. Reducing the cost of shipping goods and services - globalization - enables clusters of activity to form, since production no longer has to take place close to consumption. This allows regional disparities to develop, particularly if clusters are associated with high productivity. But in the limiting case where connectivity is perfect, and goods, services, capital, and knowledge are equally accessible from all places, then geography is immaterial — the 'death of distance'. We are back in the textbook model of firms moving to the lowest-wage places, thus removing regional wage disparities and securing factor price equalization (Fujita et al. 1999). This ambiguity makes it difficult to generalize about the effects of improving connectivity.

Moreover, the effects are highly sector-specific. In finance and some creative sectors, improved information and communications connectivity has promoted the concentration of activity. A few centers can supply services to much of the world, while at the same time benefiting from the agglomeration economies of thick local labor markets and a cluster of providers of specialist services. In other sectors, the emergence of global value chains means that value added in production of a final product has become more dispersed, helping reduce inequalities across countries. Yet different stages of production ('tasks' or functions such as R\&D and inputs of financial and legal services) have become more spatially concentrated, sometimes in just a few 
cities, so creating disparities within countries. While these global changes in connectivity will affect different regions in different ways, it is nevertheless likely that a lagging region is more likely to be an attractive destination for inwards investment, the better connected it is.

In summary, the potential movement of jobs and capital does not imply equalization of productivity, but does place bounds on spatial productivity differences. In an advanced economy with good connectivity and little variation in public capital, productivity in booming areas may be up to 60 percent higher than in lagging regions (as in Figure 1, top panel). In developing countries connectivity is probably weaker, variation in public capital is much greater, and agglomeration effects may be more powerful, yielding larger productivity variation (Figure 1, bottom panel).

\section{B. Migration and labor}

The second mechanism that should act to equalize real incomes across regions is the migration of workers to places with higher real income. Returns to mobile factors will then tend to be equalized and productivity differences will show up in the returns to immobile factors. For example, suppose that labor is perfectly mobile while land and housing is immobile and fixed. Labor mobility then tends to equalize real incomes (utility), because people leave a low wage region until the price of land and housing has fallen to a low enough level to compensate for low nominal wages. At the same time, the price of land and housing is bid up in the destination region (Combes et al. 2019), and it is landowners who capture much of the agglomeration benefits of booming cities.

But migration may fail to iron out spatial differences in real incomes. First, the gains from moving to higher productivity areas vary across individuals. Spatial wage differentials are much higher for some skill types, often skilled as opposed to unskilled workers, so migration tends to change the skill and occupational mix of different places. Second, migration is costly, financially and also because of social networks and other amenities that are lost in migration. These costs vary widely across individuals in the population. Migration from lower- to higher- wages areas is therefore income-equalizing for the marginal worker but, across the population at large, leaves spatial variation in productivity, wages, and real income. Those left behind in lower productivity areas, for whom moving costs exceed the expected present value of gains from relocation, are likely to be older and less skilled workers.

Declining areas are often subject to a vicious circle of further decline. As young, skilled workers migrate away, the local tax base and hence tax revenues diminish. In turn, this implies a deterioration in public services, such as schools, public safety, and cultural amenities (Florida 2014), and/or an increase in local tax rates (Pallagst et al. 2014). A shrinking local market may reduce any local agglomeration benefits; for instance, the "brain drain" of skilled workers decreases the region's ability to attract clusters of skilled, innovative activities (Davis and Dingel 2020, Berry and Glaeser 2005). Falling land and property prices may lock-in older residents (as owner-occupiers are unable to finance moves, particularly if capital markets are imperfect), but 
also cause a deterioration in standards of property maintenance and upgrading. Under these circumstances it becomes even harder to retain or attract skilled workers (including public sector employees, such as teachers) and inward investment by firms. The region may become locked in a downward spiral (Holmes and Ohanian 2014, Weaver et al. 2018), characterized by persistent urban decline (Glaeser and Gyourko 2005).

\section{Spatial equilibrium}

Spatially uneven outcomes may represent a "spatial equilibrium". Because of agglomeration effects, productivity is higher in a cluster or booming region than in a poorly connected lagging region. If wages are correspondingly higher in the high productivity area, then no individual firm has an incentive to move. Workers and households may have little incentive to move either, if land and property prices are low enough in the lagging region to compensate for lower nominal wages.

The nature of the spatial equilibrium poses several problems. First, this equilibrium is not generally efficient. There are multiple externalities; for example, growing a city brings positive externalities from agglomeration, and negative ones from congestion and pollution. Coordination failures mean that efficient outcomes are not achieved (see examples below). Second, as we have noted, real incomes are not fully equalized across space, for several reasons. Most importantly, migration is slow, causes adverse changes in the skill and age structure of places experiencing substantial out-migration, and creates large social costs for the 'left-behind'. In addition, there are limits to the extent to which low land and property prices can compensate for low wages - once such prices fall far enough, then housing is left vacant as the place depopulates.

\section{Growth and regional disparities in developing countries}

It is almost inevitable that a process of rapid growth and structural change starts in a few places, rather than uniformly across a country. Agglomeration forces are likely to be strong, as firms, skilled workers, large markets, and the network of supplier firms that support agglomeration are concentrated in a few large centers. This is likely to be reinforced by the spatial distribution of public capital. Transport infrastructure, power grids, and other utilities are all expensive and lumpy investments that will initially serve some regions better than others. It is efficient to concentrate them in areas of high population density and incipient, if not actual, economic activity. In addition, political institutions and policies may encourage overconcentration in excessively large cities, through a skewed allocation of public services and underinvestment in inter-regional transport and communications (Davis and Henderson 2003). In such circumstances the first-mover problem is acute, meaning that firms and workers will concentrate in the economic center, even if spatial wage differences are large. This is manifest in, amongst other things, the growth of developing country mega-cities and the problem of 'excess primacy', that is the dominance of the largest city in the overall urban hierarchy (World Bank 2009, Henderson 2002). 
From these beginnings, how is convergence likely to be achieved? Jobs are likely to spread out of central areas, as costs in these areas increase. Wages and land rents increase, and so too may costs of congestion and pollution. This spread of activity can be promoted by provision of transport and other infrastructure. At the same time, there will be movement of people towards prosperous areas, further boosting the mega-cities, and possibly creating demographic and social problems in places experiencing out-migration. It is unsurprising that countries should want to manage the balance of these two different processes, but doing so is difficult. Direct controls of population movement - the Chinese hukou system-may be effective, but are viewed as impractical or undesirable in many countries. Appropriate measures will be country-specific, but should generally support the growth of secondary cities, while at the same time accepting that some regions are likely to face population decline.

\section{E. Lagging regions in advanced economies}

International competition and technical change have created large and persistent regional disparities in a number of advanced economies. The shocks are typically sector- and placespecific, hitting a sector in which some areas have had a traditional comparative advantage, such as textiles, shipbuilding, extractive industries and, in some cases, the automobile industry. That is, regional disparities are relatively more likely to be symptomatic of negative shocks in advanced economies than in developing countries. How do places adjust to these shocks, and how is it that, in some cases, the impacts are so persistent? ${ }^{11}$

In this context, adjustment mechanisms may fail for several reasons. We have already discussed some of these issues, and two further points need to be made. First, there may be downwards rigidity in nominal wages, arising from both institutional frictions and the setting of national, rather than regional, norms. This has resulted in high levels of unemployment in many affected regions (Figure 2). More fundamentally, even with wage flexibility and full employment, there remains the question of what sectors are likely to replace those that have been lost. Many of the traditional industries that have been hit by these changes involved highly sector-specific skills that are not attractive to potential inward investors. And, fundamentally, agglomeration economies often operate at the sectoral level ("economies of localization"). This means that sectoral clusters form (for instance, in finance, technology, and the creative industries), and that the first-mover problem is strong in such sectors. Those areas that have lost traditional tradable sectors do not offer an internationally competitive environment for these new sectors. These areas do however, if wages are low enough, offer an environment for non-tradable sectors supplying the domestic economy - for instance, back-office operations, warehousing, local food processing, and public sector administration. Such areas have therefore tended to fill up with these non-tradable sectors, often offering low-skill and low-wage jobs. The difficulty of setting up new tradable sectors (especially those with localization economies) means that it is possible for a country to end up

\footnotetext{
${ }^{11}$ Austin et al. (2018) analyze this issue for the United States.
} 
both with regional disparities and with an inefficiently small tradable goods sector. This is a lowlevel equilibrium trap, brought about by the first-mover problem.

\section{POLICY REsponse}

\section{A. Spatially blind, spatially connective, and spatially targeted policies}

The geography of economic activity within countries has changed fundamentally in recent decades, in particular in advanced economies. Following a long period of regional convergence, international economic integration and technological progress that favors economies of scale and agglomeration have triggered deep structural changes within national economies, including an increasing concentration of value creation in a number of metropolitan areas. Is it possible to withstand the forces of skill-biased technological change, globalization, and agglomeration that have driven regional disparities in recent decades? Moreover, is it desirable to do so, as these same forces have also been key drivers of overall economic growth and prosperity? Hence, is there an inherent tradeoff between economic efficiency and regionally inclusive growth, or are there effective policies that can revive economic activity in declining areas without jeopardizing aggregate growth and welfare?

Traditional economic orthodoxy suggests that governments should care about people rather than places. Economic policy should focus on macroeconomic stability and building strong economic institutions that allow an efficient allocation of resources and smooth adjustment to shocks through free flows of labor and capital, while ensuring the provision of public goods and affordable access to basic services such as primary health care, education, sanitation, and security. Policy makers should focus on attaining spatial inclusiveness by promoting equality of opportunity rather than even economic activity across regions. Progressive taxation systems and social protection could help achieve more equal outcomes in terms of disposable real incomes and living standards.

As a result, spatially blind, people-based policies would generally be the first choice to address regional disparities in countries where labor and capital are mobile (World Bank 2009). These are universal policies applied on a national level, which do not explicitly focus on lagging regions, but which can nevertheless assist them by assisting lagging households. Such policies could include measures to:

- $\quad$ Strengthen public services such as health, education, and utilities (for instance, rural electrification).

- $\quad$ Ensure that interregional transfers, stemming for instance from a progressive tax system and social protection, as well as nationwide economic regulations, all assist lagging households.

Spatially connective policies could complement spatially blind policies, by connecting peripheral areas to markets, facilitating the movement of goods, services, people, and ideas, 
integrating lagging and leading areas, and thereby promoting interregional convergence. Such measures could include:

- Infrastructure investment in highways, railroads, ports, airports, and public transportation, as well as in information and communication networks. The return to these policies will be especially high where lagging regions nevertheless enjoy relatively high economic density.

- Efforts to facilitate the movement of people from lagging regions to more prosperous ones ("mobility towards opportunity").

However, the experience of recent decades raises some doubts as to whether these standard policy prescriptions are sufficient to overcome regional divides and promote opportunity. While spatially blind and connective policies may help many skilled, young, and ambitious people in lagging regions move toward better opportunities in booming regions, the majority of the population is less mobile and may remain stuck in their declining home regions. In some (mostly developing) countries, inter-regional mobility is inherently hindered by geographic, social, cultural, or ethnolinguistic divisions. Moreover, mobility is not always towards opportunity: while mobility in most OECD countries is indeed towards urban metro centers (OECD 2018), for the United States a much higher share of moves has been between lagging ('low-vitality') regions rather than from less to more dynamic regions (Nunn et al. 2018). In many advanced economies, the declining demand for lower-skilled labor and steep increases in housing costs in booming regions have further reduced migration from lagging regions (Nunn et al. 2018, Bayoumi and Barkema 2019, Hsieh and Moretti 2019). This limited mobility has contributed to high and persistent non-employment rates in some regions that have experienced deindustrialization and economic decline (Austin et al. 2018). In this context, unemployment is a far more important determinant of discontent than low earnings - increasing social strains in economically depressed regions are linked to a lack of jobs rather than of disposable income (Austin et al. 2018, Neumark 2018).

All this suggests a case for spatially targeted, place-based policies that make lagging regions more attractive places in which to create jobs, for instance by supporting local demand and improving business conditions, as opposed to people-based redistributive policies that aim to address skewed economic outcomes. Regionally focused incentives could encompass:

- Location-specific favorable tax treatments, investment subsidies, special regulations, and investment climate reforms.

- $\quad$ The targeted location of public employment, and public funding of research and higher education facilities or local infrastructure.

Economists have traditionally been skeptical about the effectiveness of spatially targeted policies, and concerned about their distortionary side-effects. The conventional wisdom is that such policies have at best mixed effects (Neumark and Simpson 2015). Their impacts have often 
been limited and not sustainable. Sometimes, they largely amount to beggar-thy-neighbor policies that shift activity and employment from one place to another (Ehrlich and Overman 2020). That said, infrastructure policies seem to work better than tax exemptions, or employment and investment subsidies. For instance, in the United States, the Tennessee Valley Authority generated significant improvements in that region's infrastructure, with a lasting impact on its development. But even in this case, the local manufacturing agglomerations it engendered were offset by losses in the rest of the country (Kline and Moretti 2014). The fiscal costs of interventions can be high, and favoring some regions over others generates horizontal-equity concerns (Gbohoui et al. 2019). Other possible side-effects include distorted migration and the capitalization of the benefits into housing costs (Austin et al. 2018). Moreover, the case for place-based policies was historically weak against the backdrop of a long period of regional convergence and high inter-regional mobility.

Nevertheless, spatially targeted policies never completely fell out of policymakers' favor, and the case for them has strengthened over time, given persistently high and/or widening regional disparities, lower inter-regional mobility, and the social and political costs of the deindustrialization and economic decline of entire regions. Some market failures may be best addressed at the local level_-for instance, localized productivity spillovers, or when not-working rates and employment elasticities are both comparatively large in distressed regions (Austin et al. 2018). Even where efficiency arguments for such policies are weak, they could help insure individual regions against place-based shocks, and address equity concerns (Gaubert et al. 2021).

\section{B. Firms, jobs, and capital}

We now examine the case for some of these policies in greater detail. We focus first on measures to boost job creation, including both spatially connective policies, and place-based policies such as the localization of public investment and public employment, tax or spending benefits for businesses and/or individuals, and regulatory relief measures. Policy measures can be explicitly spatial (such as the U.S. Appalachian Regional Commission, the Mezzogiorno tax credit for Italy's South, or the solidarity surcharge for East Germany) or implicitly spatial, for instance sectoral support for an industry that is highly concentrated in specific regions.

Public capital: infrastructure and connectivity. Spatially connective infrastructure, for instance highways, railroads, and metropolitan transit networks, can promote mobility, either by facilitating long-distance moves or by reducing economic distance, allowing commuters from further afar to participate in the economic activity of a leading region (Neumark 2018, Smith 2018). In the latter case, a metropolitan area enlarges by integrating its hinterland. A good example of a spatially connective policy initiative that goes beyond mere transport infrastructure is the concept of "ruralurban integrated cities" developed in South Korea. Launched in the mid-1990s, the policy aimed at reducing rural-urban disparities by integrating rural counties with cities in a unified spatial framework. Such frameworks encompass joint planning of transport links, land use, public service provision, and local administration (World Bank 2009). 
At the same time, physical and digital infrastructure helps connect different regions, improving the access of entrepreneurs and firms in lagging areas to the larger and thriving markets of leading areas. While better access to a large and growing market may boost some economic activity in the lagging area, it also allows companies from leading areas to compete in the periphery. Furthermore, firms from the lagging area may be lured to relocate to the leading area themselves. Thus, better infrastructure links could also further increase the concentration of economic activity. Most likely, industries that exhibit agglomeration economies would relocate to the center, while those that do not might benefit from the lower labor costs in the periphery.

Spatially targeted public investment projects are generally the most popular tool for promoting local economic development. Empirically, their record is mixed. Generally, they have been successful when they identified and targeted regional interventions with high returns, such as the electricity supply capacity created by the Tennessee Valley Authority. Such projects produced durable employment impacts and agglomeration economics, serving as incubators for private investment. However, public investment programs have failed to make a lasting impact where they did not target high return interventions, their scale was too modest, or their scope too broad. Moreover, there are risks that political pressures, limited local ownership, and the lack of thorough cost-benefit analysis produce white elephant projects with marginal benefits and possibly high follow-up costs for operation and maintenance. Policymakers can mitigate such risks through close coordination and collaboration with local authorities, businesses, and citizens, together with rigorous cost-benefit and impact analyses. The European Union's Smart Specialization Strategy is a promising approach in this regard.

To some extent, governments can also support structurally weak regions through the targeted location of government agencies, public research institutions, technology parks, or military installations. Some developing and emerging economies have gone as far as relocating the country's administrative capital in an effort to both develop the hinterland and to reduce congestion in the traditional center (for instance, Brazil, Indonesia, Kazakhstan, Myanmar, Egypt). While proximity to federal or state capitals may be important for some government agencies, others are quite insensitive to location (Yglesias 2016). Stable public or publicly funded white-collar employment could serve as a solid demand base for local economies that lack agglomeration economies and other competitive advantages. Moreover, colleges, universities, research institutions, and technology parks can also have substantial local externalities in terms of symbiotic public-private training and research partnerships, entrepreneurial start-ups, and the diffusion of knowledge, ideas, and technologies to local firms (Baron et al. 2018, Link and Scott 2018). The broad distribution of federal and state government agencies as well as research institutions has in many cases successfully contributed to the mitigation of regional disparities in Germany, sustaining the local economies of small- and mid-sized cities and creating symbiotic partnerships. Examples are the network of Fraunhofer Gesellschaft research institutes or Baden-Württemberg's universities of cooperative education, with their close links to regional small and medium enterprises. 
The regional targeting of corporate tax incentives and subsidies could be attractive if there are large regional differences in unemployment (for instance owing to the decline of a localized industry), and measures supporting employment promise to have a high return in lagging places. Many developing countries have introduced special export processing zones, some of which have been very successful as incubators for broader industrial development (such as the Special Economic Zones in China). Policymakers in advanced economies have introduced corporate investment and employment incentives in the form of tax credits, subsidies, preferential credit, or funding for workforce training to support disadvantaged regions (Neumark 2018). Examples include the United Kingdom (Enterprise Zones), United States (Empowerment Zones and Opportunity Zones), France (Zones Franches Urbaines), and the European Union's Cohesion Policy. Their results have been mixed, with both the size and the sustainability of impact being very sensitive to the time period and individual approach (Austin et al. 2018, Busso et al. 2013, Ham et al. 2011, Neumark and Kolko 2010, Greenbaum and Engberg 2004, O'Keefe 2004, Bondonio and Engberg 2000). Case studies suggest that interventions are more likely to prove successful if they build on existing comparative advantages, focus on innovative and high valueadded activities, and display close coordination between national and regional authorities and the private sector.

Region-specific tax incentives or subsidies for individuals are less common than for corporations. They are generally regressive (with benefits accruing mostly to higher-income earners), poorly targeted for regional redistribution, and may result in distorted migration to subsidized areas without incentivizing concomitant job creation. Moreover, horizontal equity concerns are likely to be more serious for individual than for corporate subsidies. That said, spatially blind national tax policy can have implicit spatial effects, as with the 2017 U.S. tax reform, which combined lower individual tax rates with caps on the deductibility of home mortgage interest, thus penalizing coastal high-tax states.

In numerous cases, spatially targeted regulatory relief measures have been combined with corporate employment subsidies in special enterprise zones. They include relaxed zoning and environmental regulations, one-stop permitting, and other simplified bureaucratic procedures. In other cases, stringent urban zoning and building regulations, such as minimum lot sizes, maximum lot occupancy rates, height and unit restrictions, or historic preservation districts have contributed to an inelastic housing supply with steep housing cost increases, restricting the population growth in booming areas (for instance the San Francisco Bay area or London).

\section{Migration and labor}

Several factors have negatively affected interregional labor mobility, often rooted in policies that have created market distortions. The most important are housing costs and social benefits (Bayoumi and Barkema 2019, Hsieh and Moretti 2019, Nunn et al. 2018, Ganong and Shoag 2017). Sometimes, discriminatory policies and residential segregation along ethnic/racial lines have contributed to and manifested inequalities on the regional or local levels (Hardy et al. 2018, Pietila 
2010). Moreover, there are also social costs to moving and leaving family and friends behind, and these costs are likely rising given ageing societies and the high cost of elderly care and childcare.

Housing costs. In some countries, stringent municipal zoning regulations, building codes, and land-use conversion rules have contributed to an increasingly constrained and inelastic housing supply in booming areas (Hsieh and Moretti 2019). The resulting steep increases in housing cost have made it unaffordable for many people to move from lagging to leading regions. ${ }^{12}$ Disincentives from high housing costs dominate the incentives from higher potential earnings, especially for people in lower-wage professions (Bayoumi and Barkema 2019). In many developing countries, insecure property rights, high transaction costs due to the lack of titles and cadasters, and limited access to credit are additional deterrents to regional mobility (World Bank 2009). Consequently, strengthening property rights and making land use, zoning, and building regulations more flexible could help make housing supply more elastic, transactions smoother, and housing more affordable. Support for investment in social housing could help increase the availability and affordability of housing in booming urban areas. ${ }^{13}$ Finally, some cities rely on rent-control regulations; these may limit the cost of existing living space, but are also likely to deter investment in new housing units.

Social benefits. Non-portability of state and local social benefits is a major deterrent to labor mobility. Public pension schemes, often explicitly designed to incentivize long-term job commitment, create strong incentives for public employees not to leave (Economist 2017). Municipal-level social benefits, such as housing vouchers, as well as federal social programs that are administered at local or regional levels (for instance, Medicaid in the United States) equally encourage people to stay put, as they may lose or have to reapply for the benefits when they move between counties or states (Austin et al. 2018). Lower living costs in lagging regions may motivate people that rely on fixed social benefits, such as unemployment insurance, not to relocate. The granting of a universal basic income could have a similar effect, reducing labor supply in booming regions (Waldman 2016). On the other hand, it would also help support demand in lagging regions. That said, both effects are likely modest.

\section{Choice of measures and implementation considerations}

There are trade-offs between spatially connective policies that strengthen mobility, and spatially targeted policies that directly support local economies. Measures that improve mobility reinforce regionally unbalanced growth and geographical concentration, withdraw the most productive workers from lagging regions, and thereby further diminish the economic

\footnotetext{
12 At the same time, depressed real estate values and slow-moving housing markets have made leaving more difficult for people that live in regions that are in economic decline.

13 For instance, Vienna, Austria, has a long tradition of providing affordable public housing; it owns or operates more than 420,000 housing units.
} 
prospects of the less skilled and mobile workers that are left behind. In contrast, place-based policies foster more balanced economic activity across regions, but may hamper overall economic growth by inhibiting an efficient spatial allocation of capital and labor. This is because the same forces that lead to a concentration of economic activity and inequality are important drivers of growth: technological progress has favored economies of scale and agglomeration, while international economic integration has created opportunities but also brought about structural change and dislocation in many local and regional economies. Misguided place-based policies could result in unproductive capital investment, and discourage efficiency-enhancing labor mobility by distorting workers' incentives to move towards opportunity. Thus, policy makers need to strike the right balance between fostering rapid but regionally uneven growth on the one hand, and promoting more inclusive regional development outcomes on the other.

Ultimately, the choice of policies must be country- and context-specific. One-size-fits-all policy interventions are not appropriate for vastly different regional economies, and there is merit in 'place-sensitive' policies tailored to particular locales. The right mix of measures may differ between advanced and developing economies, or between higher- and lower-income regions. Spatially blind and spatially targeted policy strategies can complement or counteract each other, depending on the context. The goal is always to release the development potential of all regions, and counter the under-utilization of skills and resources (Iammarino et al. 2016). To this end, "economic development policy should be both sensitive to the need for agglomeration and the need to occur in as many places as possible", to foster dynamic efficiency and maximize the aggregate economy's future innovation potential.

The appropriate policy mix will depend on the characteristics of a country's leading and lagging regions, and the key drivers of regional disparities. Sparsely populated lagging areas may be best served by people-based policies focused on providing basic public services. In contrast, large-scale infrastructure investment would likely generate low returns, and spatially targeted policies aimed at attracting business investment would be handicapped by the limited market size and shallow local labor markets. Densely populated lagging areas, on the other hand, could benefit from spatially connective infrastructure if there are no significant structural impediments to mobility, and otherwise from spatially targeted incentives and local infrastructure investment (World Bank 2009). In this context, policymakers should consider to what extent disparities reflect strong agglomeration economies, low interregional mobility, or weak interconnectedness of regional markets. Policy should also take into account the specific regional economic structures, resource endowments, and employment elasticities, as well as the presence of positive or negative externalities, and any regional targeting challenges. More broadly, in advanced regions, policies should focus on maintaining the innovative edge to keep abreast with the routinization, imitation, and geographic spread as technologies mature. In lagging lowerincome regions suffering from limited skill pools and productive capital, policies should exploit wage competitiveness, and boost local capacity through active labor market policies, education reforms, and university-industry linkages to foster skill development and innovation absorption. Policy makers must also bear in mind the potential for reforms to trigger out-migration of the 
skilled and young, resulting in negative demographic dynamics that further undermine economic and social creativity.

Authorities should also consider fiscal costs, policy space, and implementation capacity and quality of governance at both the national and regional level (EBRD 2019). Large-scale infrastructure projects and spatially targeted policies to boost local markets, business investment, and employment are costly. They must be weighed against the expected social returns, using thorough cost-benefit analysis. This is all the more important where fiscal policy space is constrained and spending needs to be prioritized. Even where the economic returns from spatially connective or place-based policies are in principle high, if the quality of governance and the government's implementation capacity are weak, then actual outturns will likely suffer from delays, wasteful spending, rent-seeking behavior, or outright corruption. In such contexts, the focus should be first on strengthening governance and institutions, including property rights, land regulations, economic management, and planning and implementation capacity at the national and subnational level. Related considerations include the design of intergovernmental financial relations, the presence of vertical fiscal imbalances, and the level of fiscal and political decentralization, which will determine which level of government should be responsible for the design, implementation, and monitoring of policy measures (Bartolini et al. 2016, Gbohoui et al. 2019).

Governments must also take into account political economy considerations, including society's preferences regarding interregional redistribution. Where the public's appetite for spatial redistribution is low in general, or limited by the existence of cultural, ethnic, or political divisions between regions, the focus should be on spatially blind national policies with the potential to assist disproportionately lagging regions. These could be complemented by spatially connective measures to help reduce regional divisions over time.

\section{E. Case studies: German reunification, and the Italian Mezzogiorno}

We now illustrate the arguments through two case studies of place-based policies. The first, German reunification, proved relatively successful. The second, the Italian Mezzogiorno (South), less so.

\section{German reunification}

When Germany was reunified in 1990, the East lagged far behind the West in economic performance and living standards. Labor productivity in the East was 30 percent of that in the West. The conversion of East Germany's currency into West Germany's at parity, rapid wage increases in the East stemming from the national bargaining system and generous public-sector salaries, and the adoption of Western labor regulations created a massive revaluation shock for East German firms. The short-term result was large-scale deindustrialization and mass unemployment. 
But over time the East largely converged with the West. Manufacturing grew rapidly, and new industrial clusters emerged. In 2019, GDP per capita and disposable income in the East stood at, respectively, approximately 75 percent and 85 percent of Western levels, and the cost of living was lower. Indeed, growth in the East outstripped that in most eastern European countries, despite starting from a higher base. Unemployment fell from a post-reunification high of 20 percent to 7 percent. Life also improved drastically across a range of other measures: the life-expectancy gap closed, and the air became cleaner. That said, convergence has largely stalled since 2000 and remains incomplete, in terms of productivity as well as educational attainment and unemployment.

The East benefited from significant assistance from the West. Financial transfers from the West to the East equaled, for extended periods, about one-third of the East's GDP, and are still on the order of 10 percent of GDP. Most transfers took the form of pension and unemployment benefits, supporting consumption. But there was also significant investment in infrastructure (20 percent of all transfers), support to companies, including investment subsidies ( 9 percent), and investment in technical universities.

This regional policy faced challenges, but also enjoyed successes. Capital invested in the East was substantially less productive and profitable than in the West (Schalk and Untiedt 2000). A disproportionate share of investment went into capital-intensive sectors, such as chemicals, automotive, and microelectronics, resulting in relatively little value-added and employment creation. Relatedly, the East experienced significant net emigration toward the West, especially among the young. Nevertheless, investment incentives were effective in boosting regional investment, employment, and growth, especially in manufacturing but also in business services (Demary and Röhl 2009). Regional policy also promoted growth in labor productivity, particularly in the less developed regions (Alecke et al. 2013).

\section{The Italian Mezzogiorno}

In contrast, Italy's Mezzogiorno has suffered from extended economic under-performance. Italy's regional divide has proved extremely persistent. Its South has displayed little convergence with the North over the past century. The South's GDP per capita remains little over half that of the North, its unemployment exceeds 20 percent, and it only attracts 1 percent of Italy's inward FDI. One consequence is continued large emigration from the South, particularly of the young and skilled. Political integration has delivered some convergence in consumption, supported by large transfers, although poverty rates remain twice as high in the South. But productivity convergence ultimately requires catch-up in the production of increasingly complex tradables. And this remains hampered by poor institutional quality, as well as labor market rigidities including nationwide centralized wage bargaining (Boeri et al. 2019, Boltho et al. 2018).

Regional policy in Italy only enjoyed short-lived successes. The period after World War II saw massive assistance to southern Italy through the State-owned Cassa per il Mezzogiorno (19501984), modeled on the Tennessee Valley Authority. It concentrated first on agriculture and infrastructure; after the late 1950s it turned towards industry, and especially capital-intensive 
sectors. It proved effective in the first two decades, thanks to its remarkable technical autonomy in planning initiatives and distributing funds (Felice and Lepore 2017). Indeed, the 1951-1973 period saw the only episode of convergence of the South towards Italian and European averages. But starting in the 1970s the agency lost its autonomy, progressively becoming an instrument of waste and misallocation, and the South once more fell behind. Subsequently, the EU "Structural and Investment Funds" for regional policy, and the Patti Territoriali community development policies which emphasized local autonomy in designing interventions, have not in general helped raise productivity or employment in the South (Ciani and de Blasio 2015, Accetturo and de Blasio 2012, Aiello and Pupo 2012, Percoco 2005). Spending on infrastructure and in highly urbanized areas did prove relatively more successful than subsidies to firms, or purchases of goods and services.

Weak institutions largely underlie the failure of regional policy towards the Mezzogiorno. Difficulties persist in managing public money and in identifying clear objectives. Poor governance, manifested in political clientelism and pervasive corruption, turns regional development funds into instruments of patronage. Regional policy is captured by local and national elites, and distorts incentives by encouraging rent-seeking rather than entrepreneurship (Felice 2018). Organized crime, feeding off development programs, compounds the challenges (Leonardi 1995). As a result, despite large regional development expenditure, the South continues to suffer from relatively poor physical and digital connectivity, and lower-quality education. And, within the South, regional investments were more likely to raise productivity in areas characterized by higher institutional quality (Albanese et al. 2020).

\section{Conclusions}

Levels of economic activity and welfare differ sharply across sub-national regions, in both advanced and developing economies. In advanced economies, the rise in regional disparities appears to be associated with economic shocks and de-industrialization since the 1980s. In developing economies, regional disparities are instead often associated with economic takeoffs that spread unevenly across regions. These persistent disparities largely reflect clustering forces ("economies of agglomeration"), which generate spatial differences in productivity and living standards. The differences may be especially large in developing countries, reflecting wide variation in the provision of public services. The movement of jobs to lower-wage regions, and of people to higher-wage regions, may fail to iron out such differences, while plunging declining areas into a vicious "death spiral". Such regional disparities raise equity concerns. They may have harmful implications for economic efficiency, as limited opportunities for those stuck in the wrong place lead to the underutilization of potential. And they can fuel social tensions.

It remains uncertain how future technological and societal trends will affect these regional disparities. Advances in communications technology, whose adoption was sharply accelerated by the COVID-19 pandemic, have increased the scope for remote work, especially in high-skilled sectors and occupations (Clancy 2020). In response, workers and firms may increasingly move out of large, expensive, congested, commuter-driven conurbations towards smaller cities and 
towns, while still reaping the benefits of a broadened pool of potential employers and employees. Geographic inequality would then diminish. However, it remains unclear how large-scale, fulltime remote work would affect productivity (Choudhury et al. 2020, Bloom et al. 2015), and in particular learning and innovation (Sandvik et al. 2020, Cornelissen et al. 2017). More broadly, large cities have a long history of adapting to overcome challenges such as epidemics or the decline of manufacturing districts (Glaeser 2020). They may yet again prove resilient (Florida et al. 2020).

If market forces alone do not bring about convergence across regions, a first line of action lies in spatially blind, people-based policies, which address regional disparities by assisting lagging households. Examples include measures to strengthen basic services such as health and education, and to ensure that national tax and social benefits systems assist underprivileged households.

Such measures may be usefully complemented by spatially connective policies, which aim to connect peripheral areas to markets, facilitating the movement of goods, services, people, and ideas, and thereby promoting interregional convergence. Examples include infrastructure investment in transportation, as well as information and communication networks, and measures to facilitate migration by reducing housing costs in leading regions and enhancing the geographic portability of social benefits.

In addition, there is a role for spatially targeted, place-based policies, focused on creating regional employment, particularly where there are significant obstacles to factor mobilitywhether of workers to more dynamic areas, or of firms to lower-wage regions. Examples include regionally focused public-investment projects, the relocation of government agencies and research institutions, and location-specific tax incentives and regulatory relief.

The appropriate policy mix will be country- and context-specific. It must depend on the characteristics of a country's leading and lagging regions, and the key drivers of regional disparities. Ultimately, policy makers must strike the right balance between fostering rapid but regionally uneven growth on the one hand, and promoting more inclusive regional development outcomes on the other. 


\section{REFERENCES}

Abel, J., and R. Deitz. 2019. "Why Are Some Places So Much More Unequal Than Others?". Federal Reserve Bank of New York Economic Policy Review.

Accetturo, A., and G. de Blasio. 2012. "Policies for Local Development: An Evaluation of Italy's 'Patti Territoriali'”. Regional Science and Urban Economics.

Aiello, F., and V. Pupo. 2012. "Structural Funds and the Economic Divide in Italy". Journal of Policy Modeling.

Albanese, G., G. de Blasio, and A. Locatelli. 2020. "Does EU Regional Policy Promote Local TFP Growth? Evidence from the Italian Mezzogiorno". Papers in Regional Science.

Alecke, B., T. Mitze, and G. Untiedt. 2013. "Growth Effects of Regional Policy in Germany: Results from a Spatially Augmented Multiplicative Interaction Model”. Annals of Regional Science.

Atkinson, R., M. Muro, and J. Whito. 2019. The Case for Growth Centers: How to Spread Tech Innovation Across America.

Austin, B., E. Glaeser, and L. Summers. 2018. "Jobs for the Heartland: Place-Based Policies in $21^{\text {st }}$-Century America". Brookings Papers on Economic Activity.

Autor, D. 2019. "Work of the Past, Work of the Future". AEA Papers and Proceedings.

Autor, D., D. Dorn, and G. Hanson. 2013. "The Geography of Trade and Technology Shocks in the United States". American Economic Review.

2013b. "The China Syndrome: Local Labor Market Effects of Import Competition in the United States". American Economic Review.

Avitabile, C., R. D'Souza, R. Gatti, and E.W. Chapman. 2020. Insights from Disaggregating the Human Capital Index. Washington, D.C.: World Bank Group.

Baron, J., S. Kantor, and A. Whalley. 2018. "Extending the Reach of Research Universities: A Proposal for Productivity Growth in Lagging Communities". In: Shambaugh and Nunn (2018).

Barro, R., X. Sala-i-Martin, O. Blanchard, and R. Hall. 1991. "Convergence Across States and Regions". Brookings Papers on Economic Activity.

Barro, R., and X. Sala-i-Martin. 1992. "Convergence”. Journal of Political Economy.

Bartolini, D., S. Stossberg, and H. Blöchliger. 2016. "Fiscal Decentralisation and Regional Disparities". Economics Department Working Paper 1330.

(CInternational Monetary Fund. Not for Redistribution 
Bayoumi, T., and J. Barkema. 2019. "Stranded! How Rising Inequality Suppressed US Migration and Hurt Those 'Left Behind'”. IMF Working Paper 19/122.

Berry, C., and E. Glaeser. 2005. "The Divergence of Human Capital Levels Across Cities". Papers in Regional Science.

Bloom, N., J. Liang, J. Roberts, and Z. Ying. 2015. "Does Working from Home Work? Evidence from a Chinese Experiment". Quarterly Journal of Economics.

Boeri, T., A. Ichino, E. Moretti, and J. Posch. 2019. "Wage Equalization and Regional Misallocation: Evidence from Italian and German Provinces". NBER Working Paper 25612.

Boltho, A., W. Carlin, and P. Scaramozzino. 2018. "Why East Germany Did Not Become a New Mezzogiorno", Journal of Comparative Economics.

Bondonio, D., and J. Engberg. 2000. "Enterprise Zones and Local Employment: Evidence from the States' Programs". Regional Science and Urban Economics.

Busso, M., J. Gregory, and P. Kline. 2013. "Assessing the Incidence and Efficiency of a Prominent Place-Based Policy". American Economic Review.

Case, A., and A. Deaton. 2020. Deaths of Despair and the Future of Capitalism.

Chauvin, J., E. Glaeser, Y. Ma, and K. Tobio. 2017. "What is Different about Urbanization in Rich and Poor Countries? Cities in Brazil, China, India and the United States". Journal of Urban Economics.

Che, N., and A. Spilimbergo. 2012. "Structural Reforms and Regional Convergence". IMF Working Paper 12/106.

Choudhury, P., C. Foroughi, and B. Zepp Larson. 2020. "Work-from-Anywhere: The Productivity Effects of Geographic Flexibility". Academy of Management Annual Meeting Proceedings.

Ciani, E., and G. de Blasio. 2015. "European Structural Funds During the Crisis: Evidence from Southern Italy". IZA Journal of Labor Policy 4.

Clancy, M. 2020. "The Case for Remote Work". Iowa State University, Economics Working Papers 20007.

Combes, P-P., G. Duranton, and L. Gobillon. 2019. "The Costs of Agglomeration: House and Land Prices in French Cities". Review of Economic Studies. 
Combes, P-P., and L. Gobillon. 2015. "The Empirics of Agglomeration Economies". In: Duranton, G., J.V. Henderson, and W. Strange (ed.). Handbook of Regional and Urban Economics 5: Ch. 5.

Cornelissen, T., C. Dustmann, and U. Schönberg. 2017. "Peer Effects in the Workplace". American Economic Review.

Coulombe, S., and F. Lee. 1995. "Convergence across Canadian Provinces, 1961 to 1991". Canadian Journal of Economics.

Crafts, N. 2005. "Regional GDP in Britain, 1871-1911: Some Estimates". Scottish Journal of Political Economy.

Davis, D., and J. Dingel. 2020. "The Comparative Advantage Of Cities". Journal of International Economics.

Davis, J.C., and J.V. Henderson. 2003. "Evidence on the Political Economy of the Urbanization Process". Journal of Urban Economics.

De La Fuente, A. 2002. "On the Sources of Convergence: A Close Look at the Spanish Regions". European Economic Review.

De La Roca, J., and D. Puga. "Learning by Working in Big Cities". Review of Economic Studies.

Demary, M., and K. Röhl. 2009. "Twenty Years after the Fall of the Berlin Wall: Structural Convergence in a Slow-Growth Environment”. Applied Economics Quarterly.

Duranton, G. and D. Puga. 2004. "Micro-Foundations of Urban Agglomeration Economies". In: Henderson, J.V., and J-F. Thisse (eds). Handbook of Regional and Urban Economics 4: Ch. 48. Amsterdam: Elsevier.

2020. "The Economics of Urban Density". Journal of Economic Perspectives.

EBRD. 2019. Transition Report 2019-20: Better Governance, Better Economies. London.

Economist, The. 2017. "Globalization has Marginalized Many Regions in the World". Briefing, Oct. 21.

Ehrlich, M., and H. Overman. 2020. "Place-Based Policies and Spatial Disparities across European Cities". Journal of Economic Perspectives.

Farole, T., S. Goga, and M. Ionescu-Heroiu. 2018. Rethinking Lagging Regions: Using Cohesion Policy to Deliver on the Potential of Europe's Regions. 
Felice, E. 2018. “The Socio-Institutional Divide: Explaining Italy's Long-Term Regional Differences". Journal of Interdisciplinary History.

Felice, E., and A. Lepore. 2017. "State Intervention and Economic Growth in Southern Italy: The Rise and Fall of the Cassa Per Il Mezzogiorno (1950-1986)". Business History.

Florida, R. 2014. The Rise of the Creative Class—Revisited. Basic Books.

Florida, R., A. Rodríguez-Pose, and M. Storper. 2020. "Cities in a Post-COVID World". Utrecht University Papers in Evolutionary Economic Geography 20.41.

Fujita, M., P. Krugman, and A. Venables. 1999. The Spatial Economy; Cities, Regions and International Trade.

Ganong, P., and D. Shoag. 2017. "Why Has Regional Income Convergence in the U.S. Declined?". Journal of Urban Economics.

Gaubert, C., P. Kline, and D. Yagan. 2021. "Place-Based Redistribution". NBER Working Paper 28337.

Gaubert, C., P. Kline, D. Vergara, and D. Yagan. 2021b. "Trends In U.S. Spatial Inequality: Concentrating Affluence and a Democratization Of Poverty". NBER Working Paper 28385.

Gbohoui, W., R Lam, and V. Lledo, 2019. "The Great Divide: Regional Inequality and Fiscal Policy". IMF Working Paper 19/88.

Giannone, E. 2019. "Skill-Biased Technical Change and Regional Convergence".

Glaeser, E. 2020. "Cities and Pandemics Have a Long History". City Journal.

Glaeser, E., and J. Gyourko. 2005. "Urban Decline and Durable Housing". Journal of Political Economy.

Glaeser, E., and W. Xiong. 2017. "Urban Productivity in the Developing World". Oxford Review of Economic Policy.

Gollin, D., D. Lagakos, and M. Waugh. 2014. "The Agricultural Productivity Gap". Quarterly Journal of Economics.

Gordon, T. 2018. "Harnessing the U.S. Intergovernmental Grant System for Place-Based Assistance in Recession and Recovery". In: Shambaugh and Nunn (2018).

Greenbaum, R., and J. Engberg. 2004. "The Impact of State Enterprise Zones on Urban Manufacturing Establishments". Journal of Policy Analysis and Management. 
Ham, J., C. Swenson, A. Imrohoroglu, and H. Song. 2011. "Government Programs Can Improve Local Labor Markets: Evidence from State Enterprise Zones, Federal Empowerment Zones, and Federal Enterprise Community". Journal of Public Economics.

Hardy, B., T Logan, and J. Parman. 2018. "The Historical Role of Race and Policy for Regional Inequality". In: Shambaugh and Nunn (2018).

Henderson, J.V. 2002. "Urbanization in Developing Countries". World Bank Research Observer.

Holmes, T., and L. Ohanian. 2014. "Pay with Promises or Pay as You Go? Lessons from the Death Spiral of Detroit". FRB Minneapolis Staff Report 501.

Hsieh, C., and E. Moretti. 2019. "Housing Constraints and Spatial Misallocation". American Economic Journal: Macroeconomics.

Iammarino, S., A. Rodriguez-Pose, M. Storper. 2018. "Regional Inequality in Europe: Evidence, Theory, and Policy Implications". Journal of Economic Geography.

IMF. 2019. "Closer Together or Further Apart? Subnational Regional Disparities and Adjustment in Advanced economies". World Economic Outlook, October: Ch. 2.

Irwin, N. 2018. "One County Thrives. The Next One Over Struggles. Economists Take Note". In: The New York Times, June 29.

Kanbur, R., C. Rhee, and J. Zhuang. 2014. Inequality in Asia and the Pacific: Trends, Drivers, and Policy Implications.

Kemeny, T., and M. Storper. 2020. "Superstar Cities and Left-Behind Places: Disruptive Innovation, Labor Demand, and Interregional Inequality". LSE III Working Paper 41.

Kessler, J. 2018. How the Concentration of Opportunity Elected Trump. Third Way.

Kline, P., and E. Moretti. 2014. "Local Economic Development, Agglomeration Economies, and the Big Push: 100 Years of Evidence from the Tennessee Valley Authority". Quarterly Journal of Economics.

Krugman, P. 1991. "Increasing Returns and Economic Geography". Journal of Political Economy.

Leonardi, R. 1995. "Regional Development in Italy: Social Capital and the Mezzogiorno". Oxford Review of Economic Policy.

Link, A., and J. Scott. 2018. "Geographic Proximity and Science Parks". Oxford Research Encyclopedia: Economics and Finance. 
Martin, R. 2001. "EMU Versus the Regions? Regional Convergence and Divergence in Euroland". Journal of Economic Geography.

Marshall, A. 1920. Principles of Economics.

Muro, M., and S. Liu. 2016. "Another Clinton-Trump Divide: High-Output America vs LowOutput America".

Muro, M., R. Maxim, and J. Whiton. 2019. Automation and Artificial Intelligence: How Machines are Affecting People and Places.

Murphy, K.M., A. Shleifer, and R. Vishny. 1989. "Industrialization and the Big Push". Journal of Political Economy.

Nagaraj, R., A. Varoudakis, and M.-A. Véganzonès. 2000. "Long-run Growth Trends and Convergence across Indian States". Journal of International Development.

Neumark, D. 2018. "Rebuilding Communities Job Subsidies”. In: Shambaugh and Nunn (2018).

Neumark, D., and J. Kolko. 2010. "Do Enterprise Zones Create Jobs? Evidence from California's Enterprise Zone Program”. Journal of Urban Economics.

Neumark, D., and H. Simpson. 2015. "Place-Based Policies." In: Duranton, G., J.V. Henderson, and W. Strange (eds). Handbook of Regional and Urban Economics 5: Ch. 18.

Neven, D., and C. Gouymte. 1995. "Regional Convergence in the European Community". Journal of Common Market Studies.

Nunn, R., J. Parsons, and J. Shambaugh. 2018. "The Geography of Prosperity". In: Shambaugh and Nunn (2018).

O’Keefe, S. 2004. “Job Creation in California's Enterprise Zones: A Comparison Using a Propensity Score Matching Model". Journal of Urban Economics.

OECD. 2016. OECD Regional Outlook 2016: Productive Regions for Inclusive Societies.

. 2018. OECD Regions and Cities at a Glance 2018.

Pallagst, K., T. Wiechmann, and C. Martinez-Fernandez. 2014. Shrinking Cities: International Perspectives and Policy Implications.

Percoco, M. 2005. "The Impact Of Structural Funds On The Italian Mezzogiorno, 1994-1999". Région et Développement.

Persson, J. 1997. "Convergence Across the Swedish Counties, 1911-1993”. European Economic Review. 
Pietila, A. 2010. Not in My Neighborhood. How Bigotry Shaped a Great American City.

Puga, D. 2010. "The Magnitude and Causes of Agglomeration Economies". Journal of Regional Science.

Rodríguez-Pose, A. 2018. “The Revenge of the Places that Don't Matter (and What to Do About It)". Cambridge Journal of Regions, Economy and Society.

Rosenthal, S., and W.C. Strange. 2004. "Evidence on the Nature and Sources of Agglomeration Economies". In: Henderson, J.V., and J-F. Thisse (eds). Handbook of Regional and Urban Economics 4: Ch. 49.

Ross, M., and N. Bateman. 2019. Meet the Low-Wage Workforce.

Sala-i-Martin, X. 1996. "Regional Cohesion: Evidence and Theories of Regional Growth and Convergence". European Economic Review.

Sandvik, J., R. Saouma, N. Seegert, and C. Stanton. 2020. "Workplace Knowledge Flows". Quarterly Journal of Economics.

Schalk, H.J., and G. Untiedt. 2000. "Regional Investment Incentives in Germany: Impacts on Factor Demand and Growth". Annals of Regional Science.

Shambaugh, J., and R. Nunn (ed.). 2018. Place-Based Policies for Shared Economic Growth.

Shearer, C. 2016. "The Small Town-Big City Split that Elected Donald Trump".

Smith, S. 2018. "Development Economics Meets the Challenges of Lagging U.S. Areas: Applications to Education, Health and Nutrition, Behavior, and Infrastructure". In: Shambaugh and Nunn (2018).

VanHeuvelen, T., and K. Copas. 2019. "The Geography of Polarization, 1950 to 2015". Russell Sage Foundation Journal of the Social Sciences.

Waldman S. 2016. "The Economic Geography of a Universal Basic Income".

Weaver, R., S. Bagchi-Sen, J. Knight, and A. Frazier. 2018. Shrinking Cities: Understanding Urban Decline in the United States.

Wilkinson, W. 2019. "The Density Divide: Urbanization, Polarization, and the Populist Backlash".

World Bank. 2009. World Development Report 2009: Reshaping Economic Geography.

Yglesias, M. 2016. "Let's relocate a bunch of government agencies to the Midwest". 